\title{
Planning for NGOs at District-level along the River Side of Jamuna, Bangladesh: Using GIS and Remote Sensing Technology
}

\author{
Tanjinul Hoque Mollah", Takaaki Nihei \\ Graduate School of Letters, Hokkaido University, Japan
}

Copyright $(2016$ by authors, all rights reserved. Authors agree that this article remains permanently open access under the terms of the Creative Commons Attribution License 4.0 International License

\begin{abstract}
This paper emphasizes on planning and spatial distribution of NGO's provided services as education, agricultural sector, micro credit, health and sanitation to the rural poor people at districts level along the river side of Jamuna, Bangladesh. This study used satellite images from 1975 to 2015 years to identify the spatial and temporal dynamics of alluvial char as well as making the plan for the NGOs distribution to ensure the proper services for the rural poor. Every year the char land shifts due to multi-channel river flow, local topography, flood, erosion and sedimentation into the river bed as well as braided characteristics of the Jamuna River as a consequences severe damage to the agriculture, infrastructure, vegetation cover and so on. The rural poor along the river side of Jamuna suffers a lot as because they are not stable in a char land and consequently shifting one char land to another so that it requires a long term policy for the betterment of the char lands people's livelihood. The rural poor people live in remote areas that are often huge distances from centers of commerce and social services areas as a result difficulties in accessing market opportunities rural people don't get proper health facilities as well as increase high levels of illiteracy. The poor suffer from hunger, ill health, a lack of education and other environmental vulnerabilities. For all of these reasons, this paper makes a plan for sustainable development and for the optimal distance from the centers of commerce and social services areas along the river side of Jamuna, Bangladesh.
\end{abstract}

Keywords The Spatial and Temporal Dynamics, Accessing Market Opportunities, Sustainable Development and Optimal Distance

\section{Introduction}

Strategic planning delivers an outstanding opportunity to collect the opinions and demands of the local NGO's beneficiaries, managers, staff, donors, and other stakeholders of the organization. A participatory approach to strategy development can also have significant to team constructing, enhanced organizational communication [3].

Jamuna River lies within a gigantic delta complex that has been growing for millions of years and comprises the greater part of Bangladesh. Bars are important topographical features in all orders of river channels [20]. On the huge flat floodplain at the confluence of the three main rivers like Jamuna, Padma and Meghna, the livelihoods of the rural poor are primarily affected by water-related disasters, including floods, drought, riverbank erosion, cyclones, and tidal surges due to the geographical setting of the country [5]. Riverbank erosion is one of the most noticeable disasters in Bangladesh, produced a dynamic channel shifting of the rivers. It annually affects about 100,000 people including the poor, who face substantial social poverties, such as loss of homestead, lands, and agricultural crops, and being displaced to the riverine fringe land, char lands [2].

The char people and their settlements in the Jamuna River channel are under threat due to floods and linked river bank erosion [13]. The displacement of char settlement takes place in almost 3-5 times in their lifetime and widespread flooding which damages crops, infrastructure, char-land settlements and communication networks, etc. [17][19]. The char people always have to fight against natural calamities and poverty as well as food insecurity as of the unstable land [8][7][16].

The flooded area has progressively increased in the recent year (Islam, 1995) [12]. For example, the area affected by floods was $25.6 \%, 71 \%$, and $36.6 \%$ in the year of 1954,1974 and 1998 respectively whereas the 1988 flood fixed a new record for the inundated area and it is one of the worst floods in recent decades. (International Union for Conservation of Nature and Natural Resources, 1993; Ahmed and Falk, 2008; Hoper, 1998) [15][1][11].

The geographic characteristics of char landscapes, in terms of fluvial morphology and monsoon climate have 
made the char lands highly vulnerable to flood disasters [6][3][4]. The Jamuna river can discharge a great amount of water $>100000 \mathrm{~m}^{3} / \mathrm{s}$ in the monsoon season (June-September) (Ministry of Irrigation Water Development and Flood Control, 1993) [18]. The surplus water makes widespread flooding which damages the char-land settlements, agricultural crops, infrastructure, communication networks and lives. There are over 12 million poor people live in char-lands and struggle against the floods and river bank erosion [9][11].

Though it is expected that nearly about 80 percent of the villages in Bangladesh are now sheltered under NGOs activities. About 13000 NGOs are engaged in micro credit operations. The majority of these NGOs are small: the few large NGOs are Grameen Bank, BRAC, Proshika and ASA. Micro credit is provided to the poor for self-employment, income-generating activities and afforestation and other poverty reduction program [10][14]

\section{Aim and Objectives}

The broad aim of the research is to make a plan for NGO's at districts level along the river side of Jamuna, Bangladesh. This research also tries to linkage between geo-spatial database of non-government organizations and satellite images that can be of assistance for further planning.

1. Identify the spatial distribution of NGO's along the river side of Jamuna, Bangladesh

2. To highlight the chronological changes of char lands from 1985 to 2015 of Jamuna, Bangladesh

3. To develop a plan for the local NGOs to sustainable development and minimize the distance from the centers of commerce and social services areas along the river side of Jamuna, Bangladesh

\section{Data and Methods}

Fieldwork Strategy: The field work strategy is basically for the following purposes:

Intensive Global Positioning Systems (GPS) Survey: For georeferencing and geometrical correction of remotely sensed images GPS Survey played a vital role in informing maps and in identifying a number of Ground Control Points (GCPs). 30 NGOs with 175 sub-branches have been identified with the help of GPS within 126 unions (Unions are the smallest rural administrative organogram and local government units in Bangladesh) of 5 districts along the river side of Jamuna, Bangladesh. A GPS survey of all NGOs of study area was georeferenced. GCP for major infrastructures are also important. This paper has used GCPs accurately for selected unions in detail mapping and properly geo-referencing. Preliminary classified satellite images were verified during the field work. Some unknown features are visible on the remote sensing images, and the field work helped to explain these properly. A detailed questionnaire survey, interviewing and observation techniques was conducted during the field visit. It was important to understand the extent of agriculture land and the overall interpretation of data. Planning policies adopted by the local, regional and national authorities were documented. A participatory mapping method was used to understand the change of the area over 30 years using the local people's knowledge-base.

The main focus of this chapter is to provide an in-depth understanding of chronological changes of Jamuna river shifting from 1985 to 2015 using Landsat TM and WorldView-2 images (Figure: 1) and make the proper planning of NGOs distribution to minimize the distance. The sources of primary and secondary data including remotely sensed images are discussed here. The entire structure and content of the paper are highly dependent on the foundation laid in the following sections.

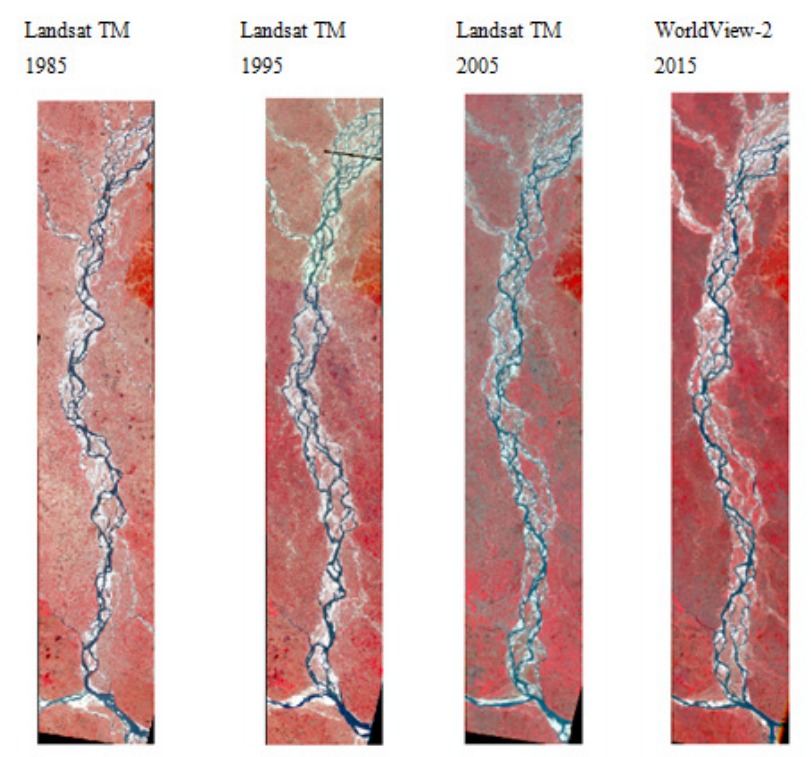

Source: Bangladesh Bureau of Statistics (BBS), The Center for Environmental and Geographic Information Services (CEGIS) and field survey, 2015

Figure 1. Above figure shows the chronological changes of Jamuna river shifting from 1985 to 2015, Bangladesh

Landsat TM and WorldView-2 images gave a unique opportunity to compare within the years and ability to show the details classification of landmass along the river side of Jamuna, Bangladesh.

\subsection{Unsupervised Classification}

This paper used unsupervised classification for separating the land and water to detail understanding the riverbank shifting. The objective is to group multiband spectral response measures into clusters that are statistically distinguishable with Digital number $(\mathrm{DN})$ values in an unsupervised classification. 

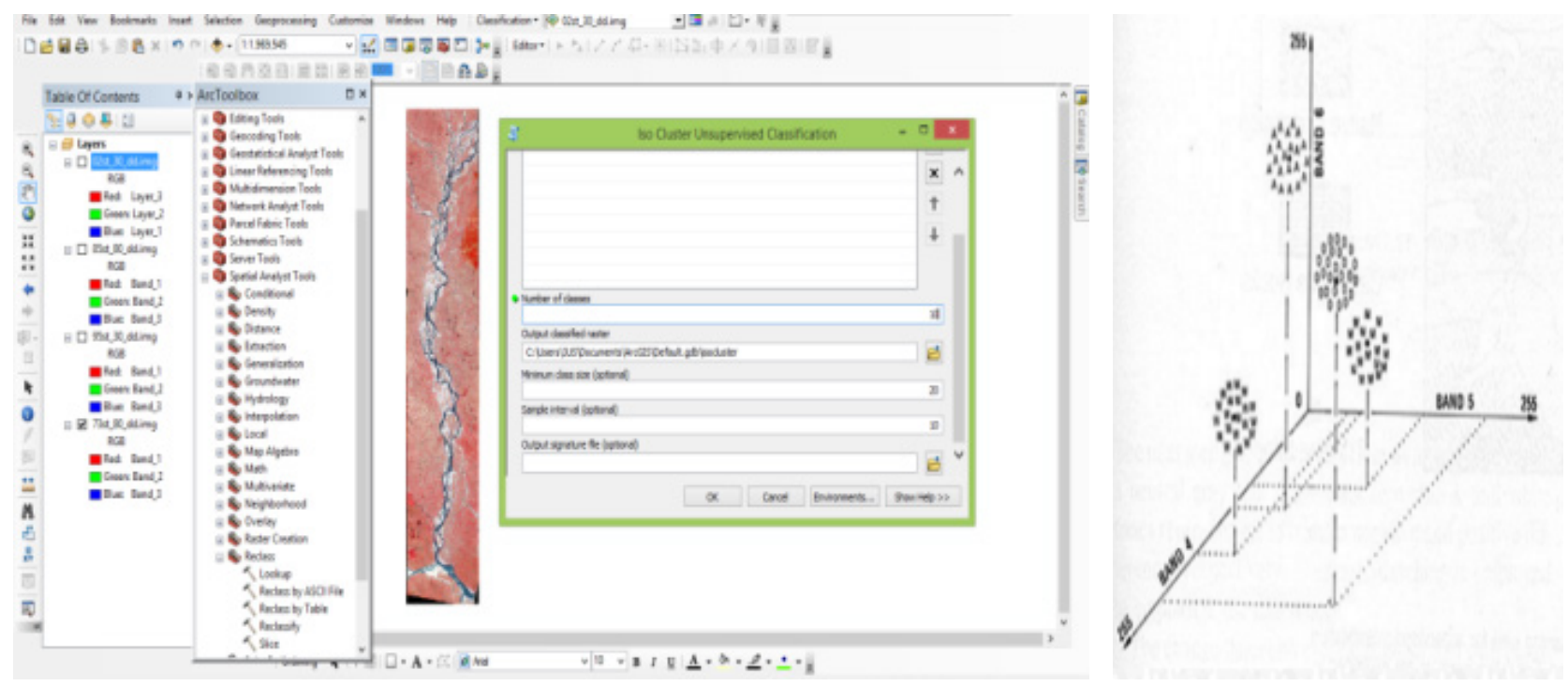

Figure 2. Unsupervised classification of the Landsat TM image using ArcGIS 10.1 software

Figure 2 shows the methods of unsupervised classification using Landsat TM and WorldView-2 images for separating the land and water to detail understanding the Jamuna riverbank shifting from 1985 to 2015, Bangladesh.

\subsection{Reclassify and Area Calculation with Percentages}

Image reclassify associated with the values of an existing map which is provided before as a function of its initial value for getting the spatial configuration linked with each map category. After image reclassification, this paper calculated the each feature percentages by the following equations:

$$
\% \text { Waterbodies }=\{(\Sigma \mathrm{Wp} / \mathrm{n}) * 100\}
$$

Whereas $\Sigma \mathrm{Wp}=$ Total number of waterbodies pixels, $\mathrm{n}=$ total number of pixel.

$$
\% \text { Vegetation cover }=\{(\Sigma \mathrm{Vp} / \mathrm{n}) * 100\}
$$

Whereas $\Sigma \mathrm{Vp}=$ Total number of vegetation cover pixels, $\mathrm{n}=$ total number of pixel.

$$
\% \text { Homestead vegetation }=\{(\Sigma \mathrm{Hp} / \mathrm{n}) * 100\}
$$

Whereas $\Sigma \mathrm{Hp}=$ Total number of homestead vegetation pixels, $\mathrm{n}=$ total number of pixel.

$$
\% \text { Char lands }=\{(\Sigma \mathrm{Cp} / \mathrm{n}) * 100\}
$$

Whereas $\Sigma \mathrm{Cp}=$ Total number of char lands pixels, $\mathrm{n}=$ total number of pixel.

\section{Study Area}

There are 126 unions of 5 districts along the river side of Jamuna under the study area and 30 NGOs with $175 \mathrm{sub}$ branches working in the said area. Districts are Sirajganj, Bogra, Jamalpur, Gaibandha and Kurigram. The second largest of the three main rivers in Bangladesh is Jamuna River. Actually Jamuna is the notable distributary channel of the Brahmaputra River as it runs from India to Bangladesh. The Jamuna River originates from a glacial part of Kailash Peak of the Himalayas, then flows to the east over Tibet and finally passes through Assam to the west and after that, The Jamuna Rivers enters into Bangladesh near Kurigram District. Riverbank erosion and deposition are common features in the study area. Road network of the rural areas is very poor (Figure 3 ).

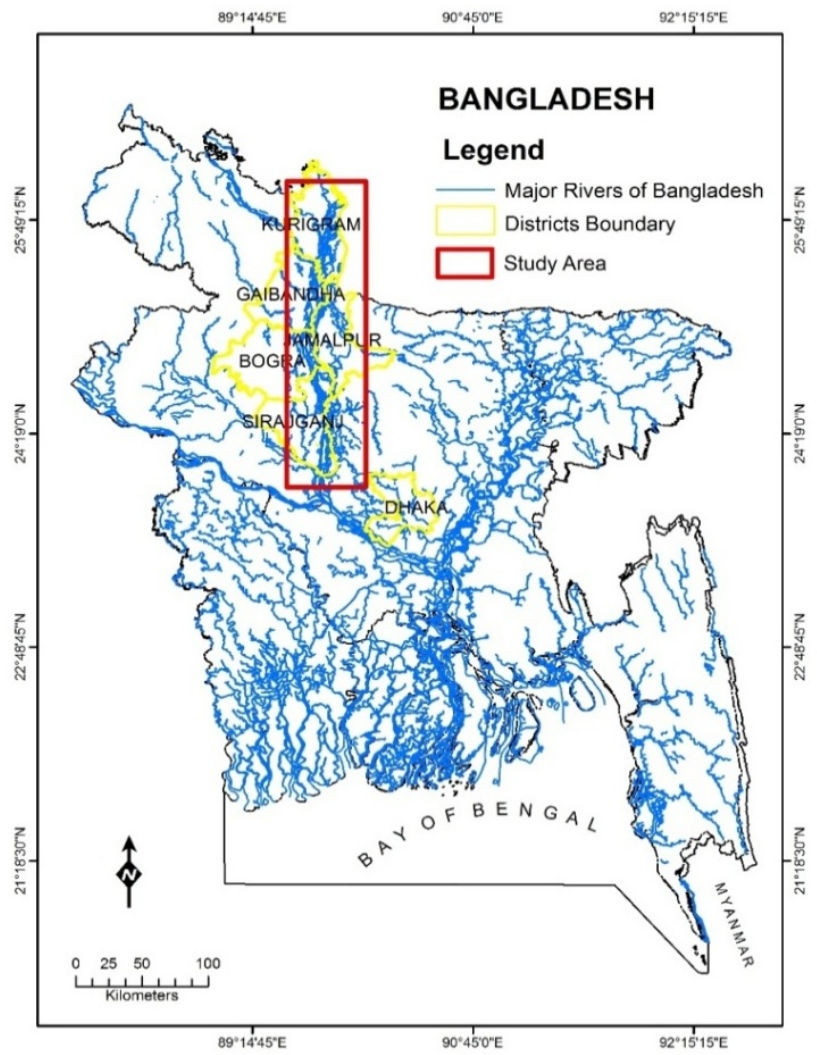

Source: Made by authors, 2015

Figure 3. Above figure shows the study area along the river side of Jamuna, Bangladesh 


\section{Data Analysis and Findings}

NGOs in Bangladesh constitute a dynamic entity which continues to table a new challenge for the intellect as well as for the policy in the country. As a body of institutional arrangement it surfaced as a result of failures in government delivery of certain social services. However, the institutional dynamics and compulsions are arising out of a participatory approach to grass roots development. The NGOs trespassed into money in the other territories. The expansion path has not always been devoid of sins. Yet the society has come to terms with their existence. From the discussion this paper would like to focus the perspective or overview of NGOs theme in Bangladesh as well as make a plan to ensure the equal facilities of the rural poor. The NGOs have engaged in the several areas and in most of these areas are rural and vulnerable with erosion actions. There are other actors in the field with whom performance of the NGOs maybe compared. In some such activities, the society may gain by providing a larger space to the NGOs substituting for the old agents. While other a new form of partnership between old agent (Both government agencies and private agencies) and the NGOs maybe envisaged. Our analysis takes into cognizance the possibility of nonprofit organization transcending into one which undertakes commercial ventures to give priority to economic efficiency and yet continues to subsidies programmes with social objectives. It is also true that the dynamics within the NGOs the internal incentives, the pressure of donors and the domestic government, all shape the scope and character of NGOs activities in Bangladesh.

\subsection{NGOs Spatial Distributions}

In the study area there are 30 NGOs with 175 sub branches (Figure 4) have been working in different sectors and all NGOs are project oriented. These NGOs are working on education, agriculture, microcredit, health and sanitation sectors. Most of the local NGOs did more attention to the microcredit sector only for profit. For the financial security of the family the local poor people became a member of the NGOs and borrow money with some rules and regulations in a particular season. Along the river side of Jamuna, there is no transportation system as a result that maximum rural poor could not get the proper facilities form the NGOs.

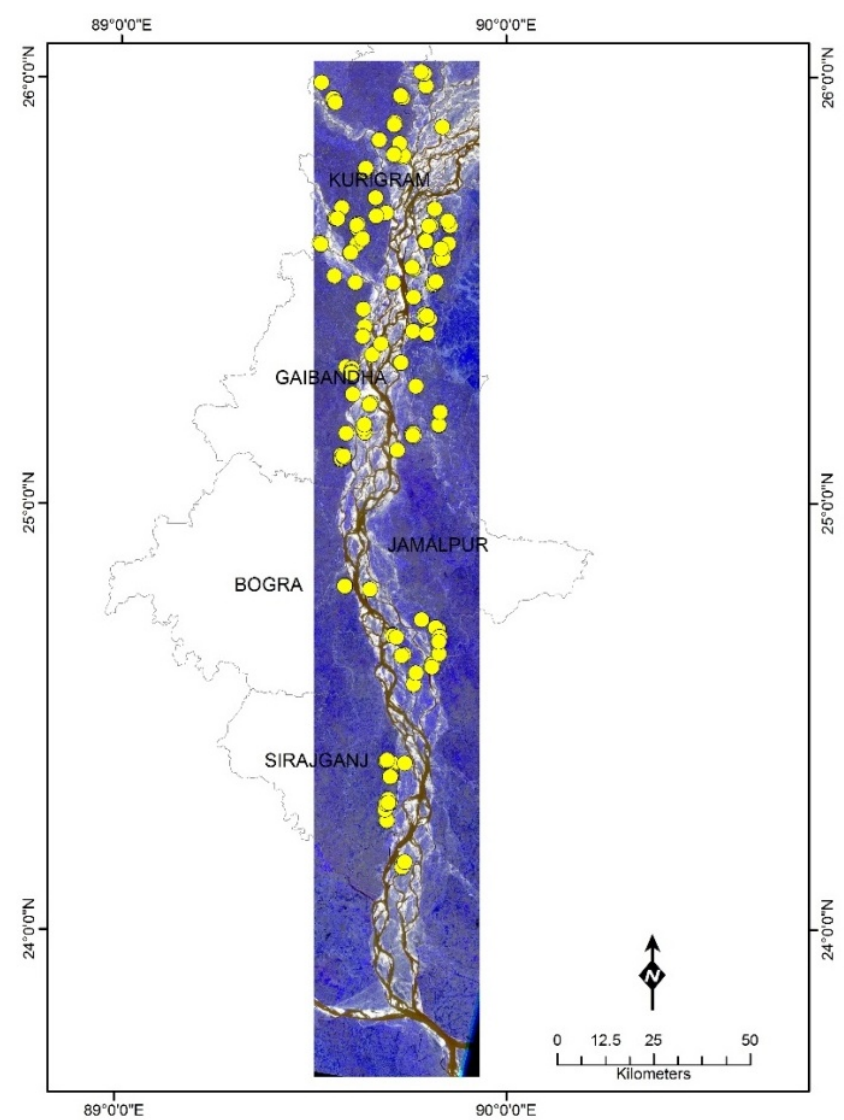

Source: Bangladesh Bureau of Statistics (BBS), The Center for Environmental and Geographic Information Services (CEGIS) and field survey, 2015

Figure 4. Above figure shows the spatial distribution of local NGOs along the river side of Jamuna, Bangladesh

Table 1. Distribution of NGOs in different areas

\begin{tabular}{|c|c|c|c|}
\hline S1 & Categories & $\begin{array}{c}\text { NGOs } \\
\text { Branches }\end{array}$ & Comments \\
\hline 1 & $\begin{array}{c}\text { Char lands/ } \\
\text { Island }\end{array}$ & 21 & $\begin{array}{c}\text { Surrounded by water in the } \\
\text { dry season }\end{array}$ \\
\hline 2 & Embankment & 87 & $\begin{array}{c}\text { Within 3km aerial distance } \\
\text { from an island char }\end{array}$ \\
\hline 2 & Mainland & 67 & $\begin{array}{c}\text { More than 3km aerial } \\
\text { distance from an island } \\
\text { char }\end{array}$ \\
\hline & Total & 175 & \\
\hline
\end{tabular}

Source: Bangladesh Bureau of Statistics (BBS), The Center for Environmental and Geographic Information Services (CEGIS) and field survey, 2015 
Table 1 shows the spatial distribution of local NGOs in different areas like in char lands/ island, beside embankment and in mainland. Among the 175 local NGOs there are 87 NGOs located in the embankment areas where as only 21 NGOs are in the char land areas and 67 NGOs in the mainland areas. For the unequal spatial distribution of NGOs, its make some major problem for the rural development as below:

1. Problems in health sectors especially maternal and child health care services because of huge distance and no transportation system especially in summer seasons.

2. Childhood illness in the rural areas

3. Least of NGOs clinics provide the service under the banner of Smiling Sun

4. Rural poor did not get proper facilities in education sector due to distance

\subsection{Chronological Changes of Char Lands from 1985 to 2015 of Jamuna, Bangladesh}

\subsubsection{Upper Stream of Jamuna River (Zone- A)}

The flowing direction of river, growing char lands are depends on the flow velocity, sediment intrusion, influences of other tributary of a river. The main stream of Jamuna river is flowing with some other tributary river, i.e., Tista, Dudhkumar etc. This tributary rivers influence the main river to increase the flow velocity as well as the direction of flow, sediment intrusion and so on. For these reason river always does not go throw the same direction and sometimes it changes. Along with the changes of river direction char land is created in front of the river or alongside the river. Mainly char land is created because of heavy sediment intrusion to the river flow.

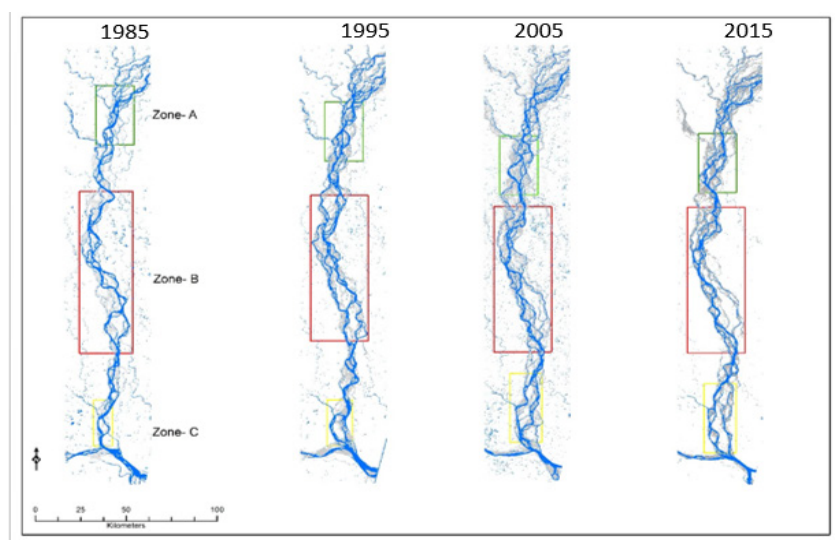

Source: Bangladesh Bureau of Statistics (BBS), The Center for Environmental and Geographic Information Services (CEGIS) and field survey, 2015

Figure 5. Chronological changes of char lands from 1985 to 2015 years of Jamuna, Bangladesh

The change of river flow direction in Jamuna is very rapid. Main reason for this changing of flowing way is high water velocity and wave action. Figure 5 shows that there is more or less change in flow direction of Jamuna River very frequently from the year of 1985 to 2015 . The major changes path has been marked as three zones: zone-A, zone-B and zone-C.

In zone-A, changing nature is not so rapid from 1985 to 1995 between the connecting point of river Dudhkumar and Tista. But between the years of 1995 to 2005 the changing way has been changed at the down upper stream of Jamuna. In 2015, as the image representing there char land area is more structured than the previous year.

\subsubsection{Middle Stream of Jamuna River (Zone- B)}

Zone-B is the middle stream of the Jamuna River which is the major channel shifting zone in this study site. From the year 1985 to 1995 at the upper part of zone-B a new stream order has found its way to flow with the main stream on the western side of the river. This new branch is going on sometimes within the river and sometimes on its own direction and at one stage it has been connected with the main stream of Jamuna. This process is going on till 2005 with a little change in flow direction. But in the year of 2015, the changes of river flow appeared differently in the eastern side of Jamuna, where some branches has been almost filled up by sand and turning into char land.

\subsubsection{Down Stream of Jamuna River (Zone- C)}

The downstream of Jamuna River has been marked as zone-C and it has been connected with the river Padma in Goalonda. Here, the river channel has been shifted gradually from 1985 to 2015.

From a general point of view it is almost clear that, many new branches have been created at this phase and total width of the river area has been increased. At the upper part of zone C there is a little similarity between 1985 to 1995 and 2005 to 2015. Mainly changes start after 1995 which goes to 2005 until 2015.

In consideration of lower part, there is a presence of many tributaries comparing with earlier stage which connects with the main river Padma. It is also significant that, the appearance of new char land is frequent in the downstream of Jamuna.

Help of equation 1 to 4 percentages of the different features have been identified using Landsat TM images and WorldView-2 from 1985 to 2015.

\subsection{Land Use and Land Cover along the River Side of Jamuna}

By using equations ( 1 to 4 ), the percentages of different features like river, homestead vegetation, vegetation cover and char lands had identified. However, table 2 shows the chronological uses of land form along the river side of Jamuna, Bangladesh. After flooding of 1988 the number of char people have been significantly increased because of fertile land and raising the char areas the then period. 
Table 2. Land use and land cover along the river side of Jamuna

\begin{tabular}{|c|c|c|c|c|c|}
\hline Image & Year & Features & \begin{tabular}{|l|} 
Pixels \\
\end{tabular} & \begin{tabular}{|l|} 
Percentages \\
(\%)
\end{tabular} & Examples \\
\hline \multirow{4}{*}{ Landsat TM } & \multirow{4}{*}{1985} & River & 166509 & 10.89 & \\
\hline & & Homestead vegetation & 438552 & 22.22 & \\
\hline & & Vegetation cover & 1164044 & 58.99 & \\
\hline & & Char lands & 155562 & 7.88 & \\
\hline \multirow{4}{*}{ Landsat TM } & \multirow{4}{*}{1995} & River & 216520 & 10.96 & \\
\hline & & Homestead vegetation & 707567 & 35.85 & \\
\hline & & Vegetation cover & 874326 & 40.30 & \\
\hline & & Char lands & 174987 & 8.87 & \\
\hline \multirow{4}{*}{ Landsat TM } & \multirow{4}{*}{2005} & River & 1684234 & 12.03 & \\
\hline & & Homestead vegetation & 4550336 & 32.50 & \\
\hline & & Vegetation cover & 5841906 & 41.72 & \\
\hline & & Char lands & 1925915 & 13.75 & \\
\hline \multirow{4}{*}{$\begin{array}{l}\text { WorldView- } \\
2\end{array}$} & \multirow{4}{*}{2015} & River & 1219815 & 8.71 & \\
\hline & & Homestead vegetation & 5545885 & 39.61 & \multirow{3}{*}{ 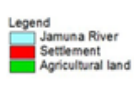 } \\
\hline & & Vegetation cover & 6547992 & 46.76 & \\
\hline & & Char lands & 688699 & 4.92 & \\
\hline
\end{tabular}

Source: Bangladesh Bureau of Statistics (BBS), The Center for Environmental and Geographic Information Services (CEGIS) and field survey, 2015

The percentages of homestead vegetation significantly growing from 1985 to 2015 which is $22.22 \%$ and $39.61 \%$ respectively whereas the vegetation cover pointedly declined which is $58.99 \%$ and $46.76 \%$ within the 30 years. The growth of vegetation and their relation with the formation process of the chars, char age and location have been analyzed by the understanding of the vegetation process on the chars. The accumulation of silt and clay at char-top has been measured from cross profiling and studied the age of vegetation. The influence of the different exogenous and endogenous factors such as large floods, bank erosion processes, and propagation of sediment wave are the main causes for char instability.

\subsection{Distance Form Char Land to Mainland}

The rural/char people and their settlements in the Jamuna River are under threat due to floods and associated river bank erosion. The overflow of water happens during the monsoon season because of widespread flooding that damages settlements, agricultural crops, and infrastructure and communication networks. Figure 6 shows the distance form char land to mainland while char land largely affected by annual floods, and as a result the char people are displaced frequently from one place to another and return to the native char when new land emerges in the river channel after floods. In dry season, char land people sometimes fall in trouble like health problem have not enough opportunities to move out another place because of transportation system. The above figure shows the minimum and maximum distance between char land and main land which is $4.5 \mathrm{~km}$ and $1.39 \mathrm{~km}$ respectively. This study is to examine the NGOs activities and spatial distribution along the river side of Jamuna and formulate a long-term strategy and planning for the char-land people in Bangladesh.

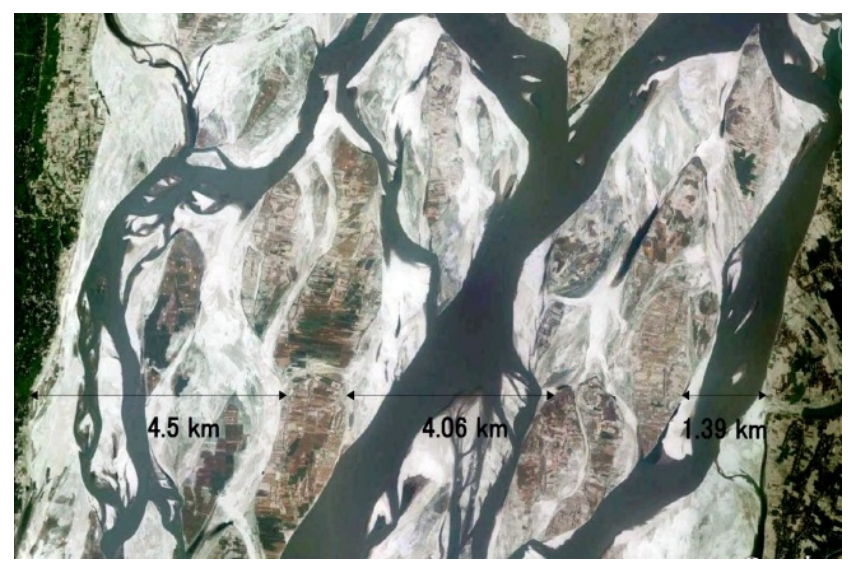

Source: Bangladesh Bureau of Statistics (BBS), The Center for Environmental and Geographic Information Services (CEGIS) and field survey, 2015

Figure 6. Distance form char land to mainland (Along the river side of Jamuna)

\subsection{Distribution of Local NGOs in Union Wise}

The overall trend of Jamuna River in the period of 1985-2015 has been eroded along the right (western) bank and accretion along the right bank. The erosion along the right bank seems to have stopped recently. It is partly triggered by bank protection works (which have been constructed since the mid-1990s), partly it also a regular process. In the downstream of Jamuna Bridge extensive accretion has occurred along with more erosional activities. Therefore, local NGOs activities along the river side of Jamuna especially on 69 unions have not reflected.

Table 3. Distribution of local NGOs in union wise

\begin{tabular}{|c|c|}
\hline Categories & Number of Unions \\
\hline Have NGOs & 57 \\
\hline No NGOs & 69 \\
\hline \multicolumn{2}{|c|}{ Total Number of NGOs are175 } \\
\hline
\end{tabular}

Source: Bangladesh Bureau of Statistics (BBS), Bangladesh Bureau of Educational Information and Statistics (BANBEIS), The Center for Environmental and Geographic Information Services (CEGIS) and field survey, 2015

There are 175 local NGOs working within 126 Unions of 5 districts along the river side of Jamuna while 57 unions have NGOs and 69 unions have no NGOs activities (Table 3). Therefore, char people are facing several problems like health, transportation, agricultural facilities, poverty and deprived from educational services.

\subsection{Relationship between NGOs Activities and Population Density}

Population accumulates the concentration of NGO. However, establishment of NGO's center according to the category is mainly based on population density. Where the density of population is more, there the concentration of NGO is also high. 
Figure 7 shows the NGOs working areas gaps by grid box. There are some unions where population density is more, though NGOs activities in that areas do not reflected.

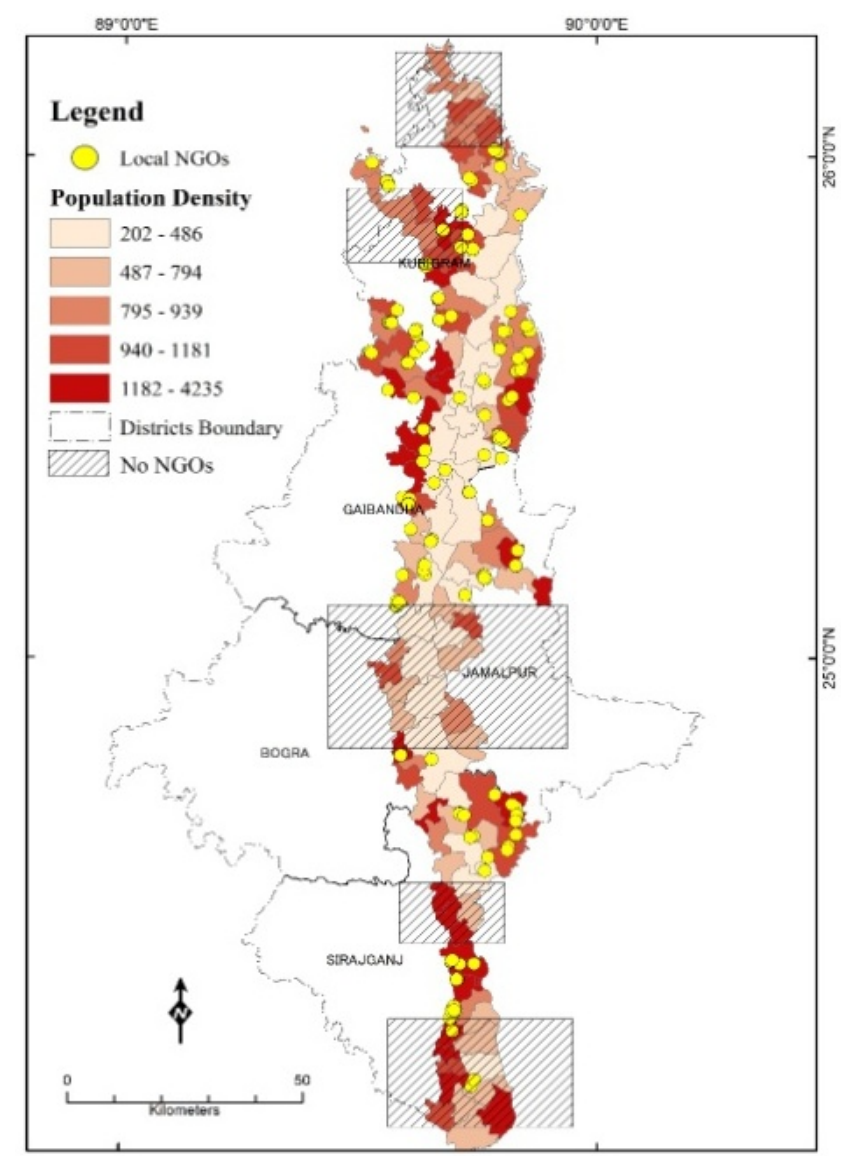

Source: Bangladesh Bureau of Statistics (BBS), Bangladesh Bureau of Educational Information and Statistics (BANBEIS), The Center for Environmental and Geographic Information Services (CEGIS) and field survey, 2015

Figure 7. Relationship between NGOs activities and population density

\subsection{NGOs Centers, Growth Center and Population Density}

Population density, growth center and NGOs activities are inextricably linked. The high concentration of people in rural area has created many economic benefits, including improved transportation links, educational, industrial and agricultural development as well as food production. The growth centers that places on the high population density areas with high concentration of NGOs activities have meant that increased of growth center is associated with rural development (Figure 8). The economic growth centers must be integrated with population density that promoting agro-processing industries in rural regions.

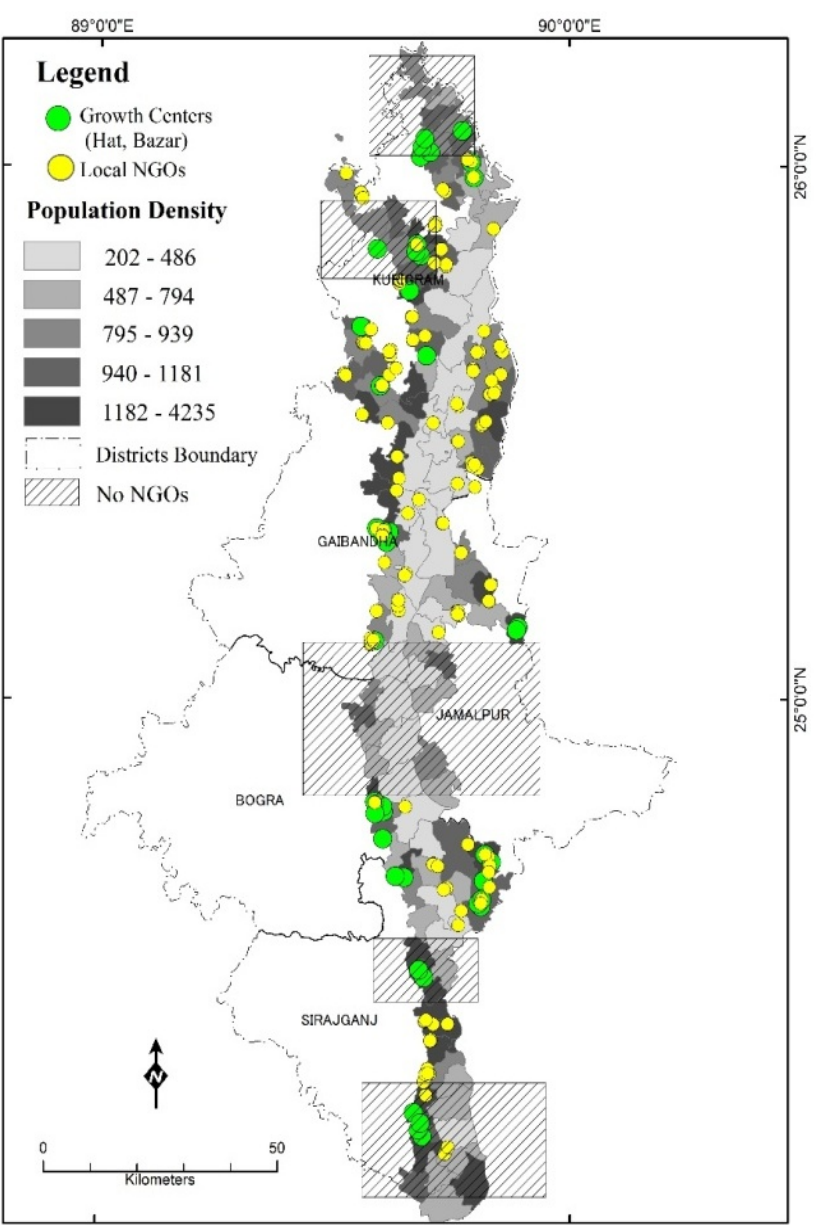

Source: Bangladesh Bureau of Statistics (BBS), Bangladesh Bureau of Educational Information and Statistics (BANBEIS), The Center for Environmental and Geographic Information Services (CEGIS) and field survey, 2015

Figure 8. Relation between NGOs centers, growth center and population density

\subsection{Planning for NGOs Using Grid Methods}

By overlapping population data and GPS data on the grids identify the more concentration areas of NGO's. This paper analyzed the concentration of NGO's within the areas and find out the unprivileged or unserved areas using overlapping methods. Health, sanitation and education would be a Category 01NGO's, agriculture is in category 02 and category 03 NGO's are less important than category 01 and 02 NGO's. Categories and Importance of NGO's depends on demand of the rural poor people as well as their perceptions and opinions (Figure 9). 

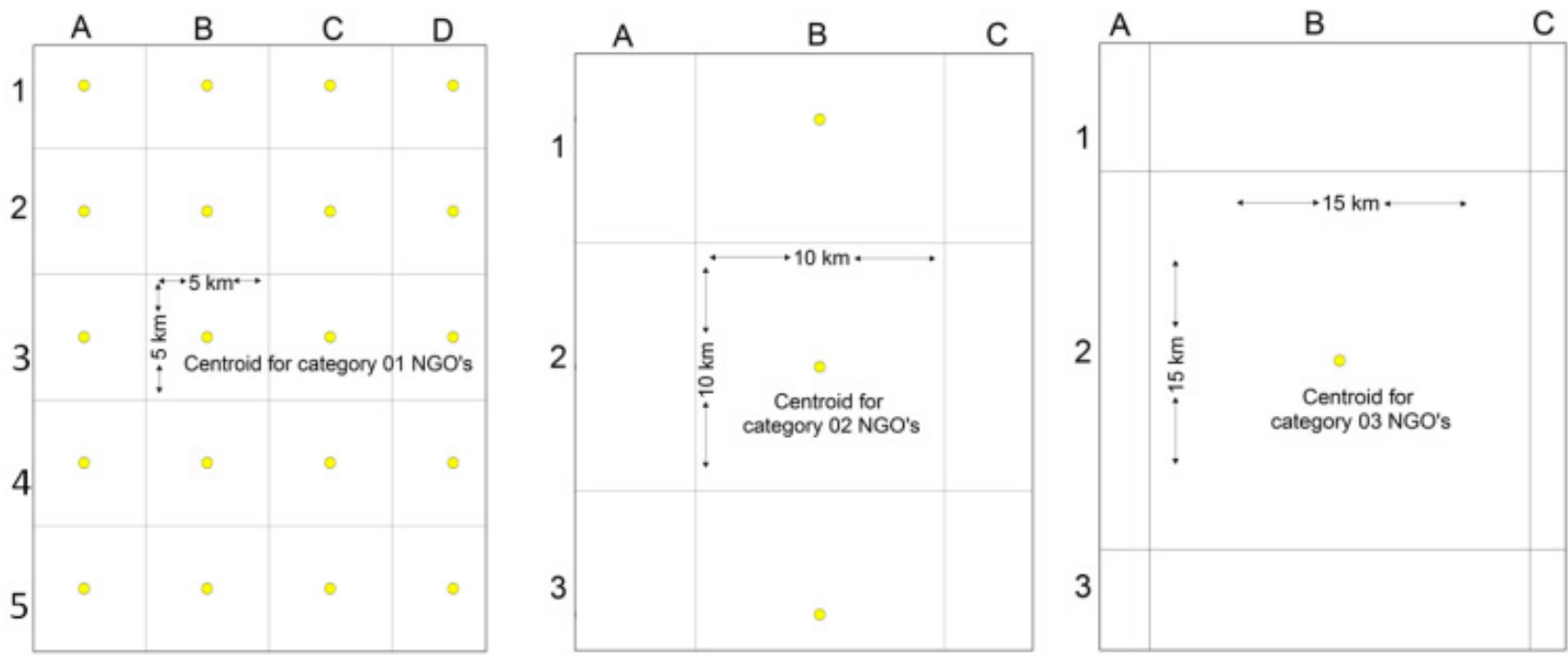

Source: Bangladesh Bureau of Statistics (BBS), Bangladesh Bureau of Educational Information and Statistics (BANBEIS), The Center for Environmental and Geographic Information Services (CEGIS) and field survey, 2015

Figure 9. Above figure shows the $5 \mathrm{~km} * 5 \mathrm{~km}, 10 \mathrm{~km} * 10 \mathrm{~km}$ and $15 \mathrm{~km} * 15 \mathrm{~km}$ grids for the planning of local NGO's for the rural people. For avoiding the huge distances from centers of commerce and social services areas and create accessing market opportunities of rural people.

The existence and impact of nongovernmental organizations (NGOs) in the rural areas of Bangladesh have radically increased over the last several decades. The distribution of local NGOs activity and the ways in which contextual factors influence the distribution of NGOs activity should emphasis on geographical location and population density. This paper explores the distribution of local NGOs activity by using grid method and identifying local factors that are linked to the distribution of NGO activity.
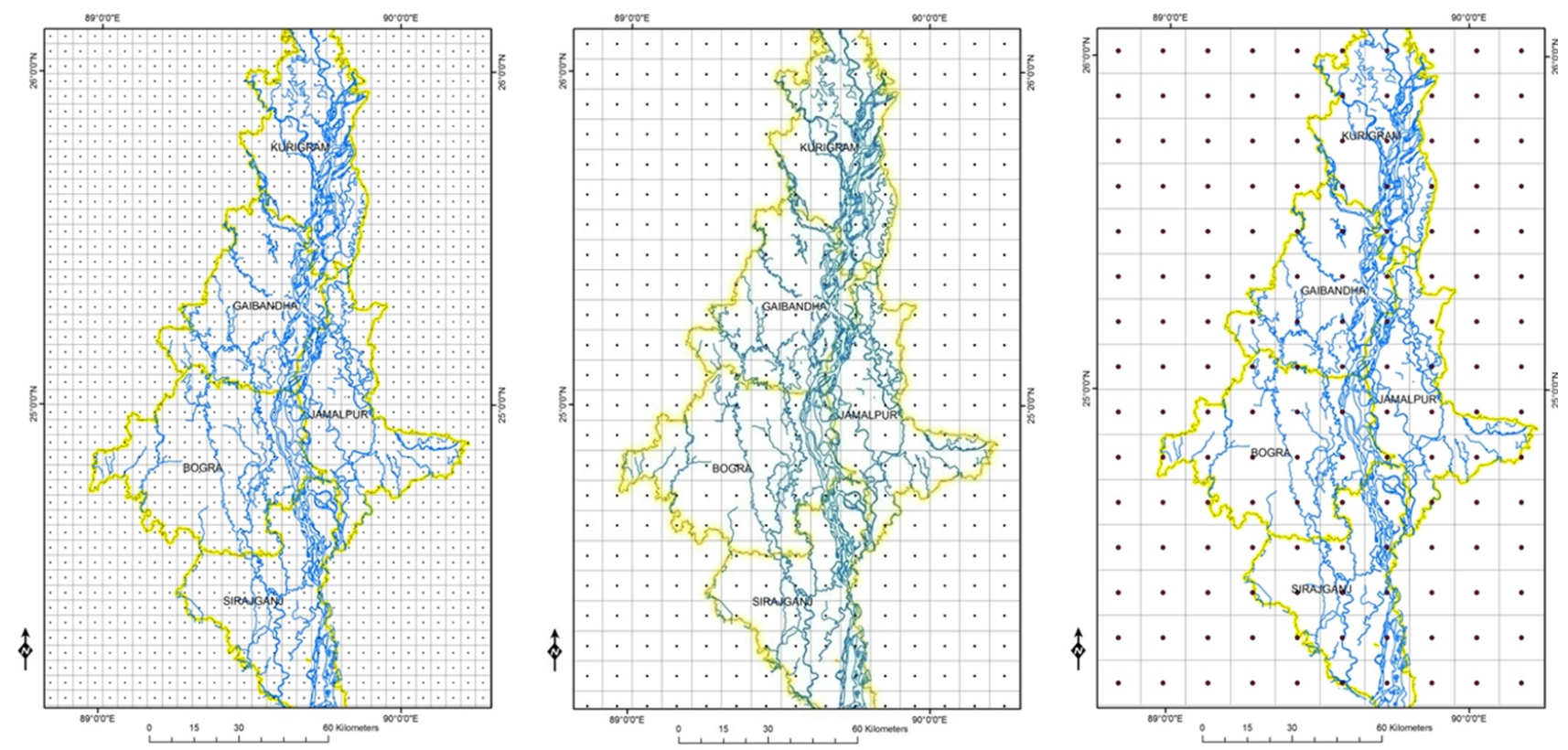

Source: Bangladesh Bureau of Statistics (BBS), Bangladesh Bureau of Educational Information and Statistics (BANBEIS), The Center for Environmental and Geographic Information Services (CEGIS) and field survey, 2015

Figure 10. Above figures show the category wise distribution in a broader view of different NGO's. According to the population density NGO's are distributed if there any physical barriers grids would be avoided.

Contradictorily, natural barrier splits up the NGO's concentration by ignoring the services. Due to natural obstruction (i.e. existence of river, river bank erosion, highly eroded area, etc.) population concentration is less here and that's why NGO's concentration is also given less priority.
In case of category 01 , the services and facilities are demanded as first priority by the local people. In this sector services are mainly related to basic human needs, i.e., health and sanitation, education facility etc. Transportation system in this rural area is not so good. The only way for moving one 
place to another is walking. If someone feels health trouble and wants to go health care center immediately becomes very tough because of less transportation facilities. For example, when a pregnant women needs to go to health center during her severe situation, it becomes challenging.

On the other side, NGO usually provide education facility at an early stage. The little kids who go to school to learn are 3-10 years old normally. $5 \mathrm{~km}$ distance is much more far for a 3 years old school going kid. At this circumstance, distance more than $5 \mathrm{~km}$ is very difficult for them to go to school where they and their family are not well known enough about value of education (Figure 10).

Considering the above facts, health and education facilities have been given first priority and concentration of NGO for this specific purpose has been set as $5 \mathrm{~km}$ distance. One important matter about education facility is that, the service should maintain continuity and they should manage a linkage with other NGO about in this condition that, after completion period of one NGO they will take all of the students to another NGO's school. As for example, the durability of one nongovernment organization is usually not more than 5 years. At this context, when a 3 years old children start to go to school then after 5 years he/she become 8 years old while he/she stood for class three or four. At the same time if that NGO wants to complete its running phase from that particular place, students who read in class three or four fall in awkward situation and some of them drop out from education.

For category 02 , priority has been given to agricultural facilities and distance of NGO's center is $10 \mathrm{~km}$. As the livelihood of this rural area depends on agriculture, the main focus of this sector is removal of economic crisis through functional agricultural systems (Figure 10).

Developing new seeds, fertilizers, new cropping methods; training for skilled farmer; multiplication of plant, plant breeding; irrigation facilities and providing agricultural tools to farmer are primarily the main concentrations of NGO in this second face.

In category 03 , the distance is $15 \mathrm{~km}$ from one NGO center to the next NGO. The concentration of this zone has been given less priority then the category 01 and category 02 . Main focus of this sector is microcredit which refers giving loan to local poor people. Sometimes the local poor does not get any financial support for their agricultural purpose or any other difficulty (Figure 10).

The loan which rural people receive from the NGO includes interest and sometimes it become hard for them to pay the whole loan with interest. NGO's authority collect the interest with due loan in vicious way. In spite of having difficulty, poor people get loan for their unavoidable cause and this loan giving organization is useful for them by all means.

As the land type of this riverside area is char land, frequent flood occurs there and there is a possibility of go down below the river water at any time. In this perspective, the structure of all infrastructures should be temporary to minimize the financial loss.

\section{Recommendations and Conclusions}

This paper having all sorts of graphical evidences, local people interviews and perceptions, focus group discussions in different categories, and documentary reviews for ensuring the proper facilities provided by the local NGOs to the poor people along the river side of Jamuna. If any further work to be initiated, these imageries and coordinates will help a clear picture of the in-situ and ex-situ survey work. The above-mentioned analysis of NGOs spatial distribution, current situations and other observations that can be make the following recommendations.

1. Local NGOs should equally allocate by using grid methods and should make integrated services for the rural poor people.

2. For the infrastructural development the projects in particular NGOs should emphasis on the local resource utilization as for examples school should make by the bamboo or using other local resources because erosional actions are presented whereas the maximum duration or the consistency of char lands are 10 to 15 years according to local people perceptions and image analysis.

3. For ensure the optimal distance, especially on summer time NGOs should provide the mobile services in everywhere.

4. NGOs should not make the permanent structure in the char land areas influencing by the projects

5. Making the link program after concluding the project duration to another project especially for the education program and ensuring it to continue.

6. For the development of rural poor, NGOs activities should established on growth center to serve microcredit facilities within the rural villages along the river side of Jamuna.

7. Make a ministry only for the char land areas which should directly look after by the government.

8. All char lands should have one boundary and ensure the same facilities for all rural people according to their needs.

9. Should increase the growth center like hat, bazar because rural development depends on proper infrastructure.

Above all discussion and data analysis conclude that proper strategy and steps makes the rural development in different sectors along the river side of Jamuna, Bangladesh. Cope with the erosional actions, proper uses of local resources, equal distribution of NGOs and integrated services of local NGOs make sure the better life style of rural poor people of Bangladesh.

\section{REFERENCES}

[1] Ahmed R, Falk G C (2008). Bangladesh: environment under pressure. Geographische Rundschau International Edition, 4(1): 13-19) 
[2] Asian Development Bank Funded by the Japan Fund for Poverty Reduction Technical Assistance Consultant's Report, Final Report, Annex E River and Char land Morphology and River Engineering, December 2013)

[3] Baqee M A (1986). Violence and agricultural seasonality in char-lands of Bangladesh. Oriental Geographer, 29-30(2): $25-36$

[4] Baqee M A (1993b). The settlement process in the char-lands. Dissertation for the Doctoral Degree. Dhaka: University of Dhaka, 1-20

[5] Chowdhury, 2010) Chowdhury N T (2010).Water management in Bangladesh: an analytical review. Water Policy, 12(1): 32-51

[6] Coleman J M (1969). Brahmaputra River: channel process and sedimentation. Sediment Geo 1, 3(2-3): 129-239

[7] Elahi K M (1991). Riverbank erosion, flood hazards and population displacement in Bangladesh. In: Elahi, $\mathrm{K} \mathrm{M}$, Ahmed S K, Mofizuddin M, eds. Riverbank Erosion Impact Studies. Dhaka: Graphosman, 95- 110

[8] Haq S (1981). Rivers of Bangladesh and their floods. Journal of Bangladesh National Geographical Association, 4(2): 1828

[9] Haque C E, Zaman M Q (1989). Coping with riverbank erosion hazard and displacement in Bangladesh: Survival strategies and adjustments. Disasters, 13(4): 300-314

[10] Holloway, Richard J. V. 1995: Civil Society - the Non-Profit Private Sector: trying to categorize it in Bangladesh, UNICF, Dhaka

[11] Hooper A G (2001). Coping with river floods in Bangladesh. In: Carpenter $\mathrm{T} \mathrm{G}$, editor. The Environmental Impacts of
Constructions. New York: John Wiley \& Sons, 213-223

[12] Islam A (1995). Environment land use and natural hazards in Bangladesh. Dhaka: Dhanshiri Mudrayan, 227-276.

[13] Islam, S. N., et al, 2010, Settlement relocations in the char-lands of Padma River basin in Ganges delta, Bangladesh, Higher Education Press and Springer-Verlag Berlin Heidelberg 2010).

[14] ISPAN, 1993. Char land Study Overview: Summary Report, FAP 16 \& 19. FPCO, Dhaka.

[15] International Union for Conservation of Nature and Natural Resources (1993). People, development and environment complex interlinkage in Bangladesh. In: Proceedings of national symposium held in Dhaka, Bangladesh. Bangkok: Dyna Print Ltd, 31-153

[16] Kabir R D (2006). The state of char education in Bangladesh: focus on selected chars of Gaibandha district. Asian Aff, 28(3): 5-24

[17] Mafizuddin M (1992). The physiography of Bangladesh: An overview. In: Elahi K M, Sharif A H M R, Kalam A K A M, eds. Bangladesh Geography, Environment and Development. Dhaka: Momin Offset Press, 20-25).

[18] Ministry of Irrigation Water Development and Flood Control (1993). Flood Action Plan-21 (FAP 21): The Dynamic Physical and Human Environment of Riverine Char-lands: Meghna, Dhaka. Dhaka: EGIS Press, 1-32

[19] Oper T (1998). Floods in Bangladesh: A highland lowland interaction. Dissertation for the Doctoral Degree. Switzerland: University of Bern, 22-62

[20] Williams, P. F., and Rust, B. R., 1969. The sedimentology of a braided river: J. Sediment. Petrol., v. 39, p. 649-679 